\title{
Materials Research and Development in India Has Rich and Rocky History
}

\author{
V.S. Arunachalam
}

The story of India's relationship with materials is ancient and rich. Archeological excavations in the Indus Valley and other parts of the subcontinent confirm the mastery of the craftsmen and the sophistication of the ancient civilizations in making, shaping, and using materials. "The Dancing Girl," a diminutive casting now at the National Museum in Delhi, is perhaps an outstanding example of one such period in Indian history. Created by the process known as lost-wax casting or cirre perdue (the Sanskrit word to describe the process, madhu uchishtavidhan, means the same thing), this figure appears to be as sound and accurate as some of today's investment-cast turbine blades!

This casting tradition, though, has not been continuous: wars, famines, and natural catastrophes have all taken their toll. Each age seemed to discover the materials anew, often unaware of their earlier discoveries and uses. Even the ancient palm-scripts (some of them had appeared well before the publication of Pirotechnicia in Europe) did not seem to help in sustaining continuity. The fact that India missed the Industrial Revolution, along with the absence of guilds where craftsmen could assemble and discuss their trade, contributed toward making the Indian saga on materials brilliant in patches, but disjointed; and this state of affairs seems to have persisted well into this century.

Until the Indian Independence, universities were the main centers for materials research. Even though only a few had teaching or research programs on materials, their research contributions were significant, and provided the nucleus for the scientists and engineers of post-independent India.

After Independence, the Indian government invested large amounts not only in setting up heavy metallurgical industries, but also in building national laboratories modeled on DSIR of Great Britain and CNRS of France. The first prime minister of India, Jawaharlal Nehru, was an aficionado of science and technology and wanted to use them as tools for India's industrial progress. Many of the laboratories set up by the Council of Scientific and Industrial Research (CSIR) in this decade were dedicated to the development of materials. Some are exclusively concerned with metals, while others are concerned with a spectrum of materials technologies. For instance, the Central Glass and Ceramics Research Institute in Calcutta has as its mandate the development of glasses and ceramics, and the National Aeronautical Laboratory in Bangalore, the development of aerospace materials.

Many new scientific organizations and commissions such as the Atomic Energy Commission, Indian Space Research Organization, and the Defense Research and Development Organizations (DRDO) were also set up by the government during this decade. Many of these organizations built up excellent laboratories to study materials needed for their own programs. The Atomic Energy Laboratories at Trombay, for instance, became involved not only with the development of nuclear materials but also with thenemerging techniques such as neutron diffraction to understand the structure of materials. Some seminal contributions on materials came from these laboratories during that period. DRDO, for instance, expressing personal points of view on issues of interest to the materials community. has laboratories devoted to the development of metallic materials, semiconductor and magnetic materials, and composites.

Even though DRDO's mandate was to develop materials required for defense applications, they have also been addressing problems of a more general nature as well. There are some recent and original contributions on titanium intermetallics, high-strength materials for armor, and powder metallurgy from the Defense Metallurgical Research Laboratories at Hyderabad; the Solid State Physics Laboratory at Delhi has developed novel methods for growing crystals of compound semiconductors and for fabricating semiconductor devices. These organizations followed the pioneering lead taken by CSIR to fund and support basic and applied materials research in the Indian Universities. Without this support, research at these centers would have withered because the University Grants Commission normally mandated to fund research at the universities had so many compelling priorities and numerous universities to sustain.

Until the early seventies, therefore, materials research was confined to universities, research laboratories, and some exclusive science organizations such as the Department of Atomic Energy. Neither the Indian industries nor the government ministries used the expertise or the vision of the laboratories to identify materials options for India, or to evolve national materials policies. Materials research by industries was also modest during those decades, with many of the company-owned centers acting as mere control laboratories to assist in trouble-free production. No noteworthy technologies, products, or processes emerged.

Some major innovations in integrating materials research programs with national priorities appeared in the 1970s. First, there was the formation of the Department of Science and Technology (DST), with a mandate to integrate and coordinate research and development with national needs and to sustain R\&D programs until their fruition. Then there was the Scientific Advisory Committee to the Cabinet (SACC), headed by the member of the Indian Planning Commission responsible for science and technology, with representatives from scientific organizations, government ministries, and industries. These structures have made a significant impact on coordinating materials research and development and integrating these with the national plan. 
DST first established the Science and Engineering Research Council (SERC) to support research and development programs, including programs on materials, and to help utilize their findings for industries. A powerful peer review system is an integral part of this council, and has been a great help in choosing programs for funding. This department has also actively sustained research laboratories such as the Raman Research Institute, Bangalore, which has become one of the outstanding centers for liquidcrystal research. The department now has another society, the Technology Information Forecasting and Assessment Council, which commissions studies on national options on materials; recent reports include a plan to set up titaniumbased industries, and one to develop electronic materials nationally.

SACC also has commissioned many reports on materials and has helped to integrate some of the recommendations of the committee in the Plan document of the country. Rajiv Gandhi, when he became the prime minister, reorganized the committee as the Scientific Advisory Committee to Prime Minister, under the chairmanship of Prof. C.N.R. Rao, with members drawn from universities, industries, and laboratories. This committee again prepared an exhaustive report on national options in materials and recommended its acceptance by the government. It was during this period that the materials community had a taste of the government's readiness to act fast: when the discovery of high-temperature superconductors was announced, Rajiv Gandhi personally presided at a meeting attended by scientists and engineers working in this area, and approved a national initiative to develop this class of materials.

A review of the performance of DST and SAC must acknowledge their contributions in breaking the barrier between research and its utilization, and in bringing industries and the bureaucratic ministries into their fold. For the first time, the industries and the other government ministries understood the national strength in materials research and development, as well as the opportunities it provided.

The past few years have shown the fruits of these efforts. Most of the ministries concerned with industries have set up scientific committees of their own to advise, and some are even using these committees effectively. On the recommendation of one such committee, India has set up a plant to manufacture carbon fibers at the Indian Petrochemical
Industries at Baroda. New steels from the research laboratories of the governmentowned steel companies of India have made it to production in the large industrial plants. Such developments had never occurred before; in the past, all steel compositions and know-how were imported from abroad. Now, even some privately owned industries are involved in materials research. For example, there is a private cement industry that has teamed up with the National Chemical Laboratory and a petrochemical compa-

Unless there is a
commitment to better
fund [Indian]
universities and to free
them from interference
of various kinds, the
traditional fountainhead
for Indian research on
materials will dry up.

ny to manufacture ceramic catalysts.

The recent economic liberalization has thrown open Indian industries to international markets and developments. The initial fears of Indian research languishing under foreign competition have not come true. Thanks to the initiatives taken by DRDO, CSIR, and DST, many laboratories have pooled their resources and formed consortia with relevant industries. Already, there are organizations at Hyderabad where the competence of laboratories in metallurgy and in fiber-reinforced composites is linked successfully with the production capabilities of industries concerned with the manufacture of civilian commercial products. True, the participation of private industry is still cautious, and not extensive; but the experience is encouraging.

There is growing political pressure to accomplish more, and to demand that government research laboratories concern themselves only with applied research in materials, leaving the pursuit of basic research to universities. Even though there is merit in this recommendation, many fear that it may go too far. Today, only the national laboratories have facilities comparable to those in the West. Competent scientists are attracted to these laboratories because of the facilities they offer for pursuing basic research. A judicious mixture is required therefore to make the laboratories relevant and scientifically outstanding. This is a difficult experiment; it would be easy to lose the delicate balance, making the scientists vulnerable to criticism.

Where does this leave the Indian universities? In spite of very poor funding, many are managing to do good research. The Benares Hindu University; The Indian Institute of Science, Bangalore; the Institutes of Technology at Delhi, Bombay, and Kanpur; and the Indian Association for Cultivation of Science all have good on-going programs in rapid solidification of materials, high-temperature superconductors, quasi-crystals, alloy phase diagrams, powder metallurgy, thin films, and photovoltaic materials. Truth to tell, these programs are being pursued on shoe-string budgets and with a minimum number of scientists. Unless there is an awareness and a commitment to better fund the universities and to free them from interference of various kinds, the traditional fountainhead for Indian research on materials will dry up, leaving behind an emaciated sector, difficult to revive. This is a serious concern for those associated with materials research in India.

The recently prepared draft on New Technology Policy now under consideration by the present government has identified materials as a high-priority area and suggests linkages for making research relevant and for finding resources for program funding. The report even talks of direct contributions from industries, in addition to the government's funding. Will India be able to achieve a synergism that would pool its scientific and human resources to be a world leader in materials research? More importantly, will India's industries be able to enjoy the fruits of national research and development programs? Will a policy finally emerge that will define priorities for materials research, development, and growth, and free the country from being a mere exporter of raw materials and human power? When this should happen, India at last will have gotten over the historical discontinuities that have debilitated its research, discoveries, and inventions. The coming years promise to be interesting.

V.S. Arunachalam is a former scientific adviser to Indian defense ministers, and past president of the Indian National Acaderny of Engineering. He is spending the current year on sabbatical as a senior visiting professor in the Department of Materials Science and Engineering at Carnegie Mellon University, Pittsburgh, PA. 